SCIENTIFIC REVIEW

\title{
PARTICIPATION OF EMPLOYEES IN THE MAKING OF MARKETING DECISIONS IN ENTERPRISES IN SERBIA
}

\author{
Nenad Ravic ${ }^{14}$, Snezana Kirin'15, Predrag Filipovic ${ }^{16}$
}

\begin{abstract}
Contemporary approaches to the analysis of business activities of modern organizational systems are focusing on human resources and considering them the most important property. Participation of employees in the decision-making process contributes to the improvement of company's performances, and also to the satisfaction and motivation of employees. Objective of this research paper is to point out to the significance of employees' participation in the making of strategic decisions in an enterprise and to examine the share of employees in the making of marketing decisions in Serbia's economy. Through empirical analysis presented in this work, we analyzed the level of involvement of employees in the process of making marketing decisions through the presentation of their attitudes depending on their personal characteristics, type of organization and their position in the organization. The results obtained say that there is room for increasing the level of employees' involvement in the process of making marketing decisions, as well as the influence of age and hierarchical positions on the possibility of influencing the decisionmaking process.
\end{abstract}

KEY WORDS: Marketing, Employees, Organization

JEL: M31

UDC: 005.5:005.331

005.573:658.8(497.11)

COBISS.SR-ID 227952396

\footnotetext{
${ }^{14}$ Corresponding author, Faculty of Business Economics and Entrepreneurship, Belgrade, Serbia,e-mail: nenad_ravic_bps@yahoo.com

${ }^{15}$ Faculty of Mechanical Engineering, Innovation Center, Belgrade, Serbia

${ }^{16}$ Faculty of Applied Management, Economics and Finance, Belgrade, Serbia
} 


\section{INTRODUCTION}

Participation of employees observed in this paper refers to the involvement of employees in the process of making decisions inside an enterprise. In order to have employees' participation in this most important segment of business, there are two usual ways: the first one implies the participation of employees' representatives in some of the leading bodies of the company, such as managing or supervising board, and the other way implies that the employees gather around an union, which would increase their power as the negotiation party. We should underline that the so-far experience has shown that organizing employees into unions is a more effective way for carrying out employees' participation in making decisions than placing employees' representatives in some of the leading bodies in the company.

Participation of employees in making decisions is very important for several reasons. First, it contributes to the increase of quality of the decisions being made, hence it leads to the improvement of company's performances, which then brings bigger salary to the employees and better work conditions. Second, participation increases the level of employees' work satisfaction because it makes them feel like they are important for the organization, that their voice is heard and respected. In that way, employees are more motivated to work harder and better.

Marketing sector is one of the company's sectors in which it is highly needed to intensify the level of employees' involvement because the survival and prosperity of the company depends on the quality of marketing decisions to great extent. In search of innovative and creative solutions regarding the development of new products and the improvement of the existing ones, regarding the creation of promo activities etc., marketing manager shouldn't, in any case, ignore opinions of the employees because they represent an important source of ideas. Because they know about the company's business activities, they have certain knowledge and experiences by which they can certainly help in making the best possible decisions.

\section{METHODOLOGICAL AND HYPOTHETICAL FRAMEWORK}

\section{Research topic}

In time, marketing function has been established as the most important function in companies and as such it deserves special attention. In this paper, research topic is the participation of employees in the making of marketing decisions in companies in Serbia's economy. Bearing in mind that a large number of different decisions is made on a daily basis in each company, authors of this research decided to focus on marketing decisions because of the enormous significance of marketing and marketing decisions for the survival and market success of companies in modern business conditions.

\section{Research objective}

Objective of this paper is to point out to the significance of employees' participation in making marketing decisions inside a company and to examine the share of employees in the process of making marketing decisions in Serbian economy. 


\section{Research hypotheses}

Based on the topic and objectives of this research, we derived the basic research hypothesis, which is: By raising the level of employees' participation in the process of making marketing decisions in companies in the Republic of Serbia, we can influence the improvement of their performances.

Special research hypothesis is:

Personal characteristics of employees influence the share of employees in making marketing decisions.

\section{Research methods}

The following methods were used in this research:

- Content analysis method - expert and relevant literature in printed and electronic form

- Deduction method, used to divide the research topic into variables;

- Induction method, which enabled a comprehensive overview of the research topic.

- Empirical research method, realized by a technique for interviewing a sample of 100 interviewees who are performing marketing business activities in companies of different size and employees' occupations. For this research, we constructed an appropriate survey in form of Likert scale. Empirical research was carried out in three stages:

1. Data collection;

2. Sorting out and grouping the data;

3. Processing the data by a method of statistical analysis and by using the IBM SPSS Statistics 21 program;

4. Interpretation of the results obtained.

\section{THE DECISION-MAKING PROCESS}

Each person, both in private and in business life, is confronted with numerous choices, problems and situations in which it is necessary to make a decision. In private life, decisions are most often made intuitively, while in the business world they are based on analyses, agreements with cooperatives and on the use of certain tools or techniques for making decisions. Making good decisions leads to a better life and it enables a certain level of control over it (Kirin, Grubic-Nesic, 2008, pp. 385-388). The process of making decisions and their realization is the key managerial activity which consists of a larger number of activities and it depends on a greater number of factors. The decision-making process is the crucial process which enables both the survival of a company, and sustainability of its efficiency (Kirin et al., 2010, pp. 465-472).

In a narrower sense, the decision-making process implies making a choice between two or more alternatives, and in a wider sense, the process of solving problems. The basic difference between managers and other employees is the organizational level and type of 
decisions they make (Kirin, 2006, pp. 15). Within an organization, managers are those who make the most important decisions which makes them different and more responsible than other participants in the business process.

According to the group of authors (Stoner et al., 2002, pp. 216), the decision-making process is the process of noticing and choosing the right path of acting in order to solve a certain problem or use a business opportunity. We should bear in mind that each problem in business can represent an opportunity to improve or innovate something. It is important to mention that the decision-making method must correspond with the problem which is being solved (Borkovic, 2009).

The effectiveness of marketing decisions has a great significance for the survival and development of a company in modern business conditions. Increased competition, brought by globalization and constant changes in environment, is forcing companies to pay more attention to the needs and wishes of consumers in order to attract and keep them (Mucunska-Pelevska, Badarovski, 2013, pp. 98). Innovative organizations combine critical factors of success to create a sustainable competitive advantage (Ravic, Minkov, 2014, pp. 3). All marketing activities covered by traditional marketing, such as: building corporate image, gathering information, attracting new clients, promotion, sales, distribution, establishing relations with customers, etc., are today being carried out via the Internet and faster, more efficient and cheaper in comparison with the traditional marketing (Ravic et al.,2013, pp. 246-262).

\section{EMPIRICAL RESEARCH}

This research was carried out on a sample of 100 interviewees who are performing marketing activities in companies of different size and occupation. Objective of this research is to examine the participation of employees in the making of marketing decisions. Senior marketing managers and marketing directors were excluded from this research because it goes without saying that they participate in the making of marketing decisions. Data were gathered by a surveying technique with the help of a questionnaire which consists of two parts: introductory part which refers to personal characteristics of interviewees and the second part which was made in the form of Likert scale. The questionnaire consists of 13 questions.

\section{RESEARCH RESULTS}

Pictures 1-6 are here to show you the distribution of agreement with opinions:

- I take part in the process of making marketing decisions in my company;

- I am satisfied with the level of personal participation in making marketing decisions;

- I am at liberty to express my opinion and suggestions concerning the improvement of business;

- Direct manager (senior marketing manager or managing director) makes all decisions independently without consulting the employees

- The quality of marketing decisions would improve if the employees would be more involved in the making of those decisions;

- I've got ideas concerning how a company could improve its marketing. 
Description of the sample is given in table 1.

Table 1: Sample description

\begin{tabular}{|c|c|c|}
\hline \multirow{2}{*}{ Sex } & male & $53 \%$ \\
\hline & female & $47 \%$ \\
\hline \multirow{5}{*}{ Age } & under 25 & $21 \%$ \\
\hline & $25-34$ & $45 \%$ \\
\hline & $35-44$ & $27 \%$ \\
\hline & $45-54$ & $5 \%$ \\
\hline & 55 and above & $2 \%$ \\
\hline \multirow{4}{*}{ Education } & High School & $39 \%$ \\
\hline & College & $25 \%$ \\
\hline & Faculty & $32 \%$ \\
\hline & Post-graduate studies & $4 \%$ \\
\hline \multirow{4}{*}{$\begin{array}{c}\text { Size of } \\
\text { organization }\end{array}$} & no more than 10 & $0 \%$ \\
\hline & $10-49$ & $63 \%$ \\
\hline & $50-249$ & $25 \%$ \\
\hline & 250 and more & $12 \%$ \\
\hline \multirow{3}{*}{ Area } & Production & $12 \%$ \\
\hline & Trade & $21 \%$ \\
\hline & Customer service & $67 \%$ \\
\hline \multirow{3}{*}{ Position } & Operative workers in marketing & $71 \%$ \\
\hline & Marketing manager's assistants & $18 \%$ \\
\hline & Junior marketing managers & $11 \%$ \\
\hline \multirow{2}{*}{$\begin{array}{c}\text { Marketing } \\
\text { sector exists }\end{array}$} & yes & $88 \%$ \\
\hline & no & $12 \%$ \\
\hline
\end{tabular}

Source: Authors' research

Interviewees expressed their level of agreement in the Likert scale from 1 to 5 . With the opinion: "I take part in the process of making marketing decisions inside the company", $58 \%$ of interviewees completely disagreed, $29 \%$ of interviewees agreed, $9 \%$ partially agreed, and $4 \%$ completely agreed. 


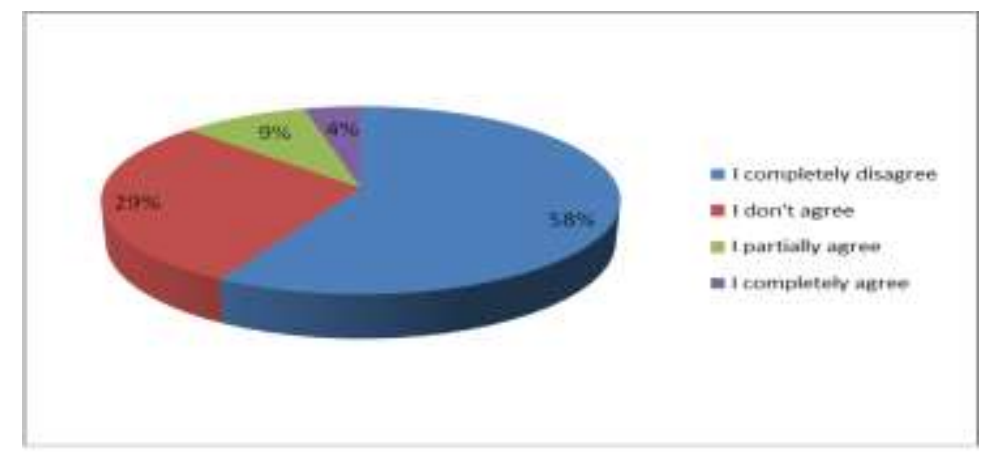

Figure 1: I take part in the process of making marketing decisions inside the company

\section{Source: Authors' research}

With an opinion: "I am satisfied with the level of personal participation in making marketing decisions", $59 \%$ of interviews completely disagreed, $31 \%$ of interviewees didn't agree, $6 \%$ partially agreed, while $4 \%$ of interviewees completely agreed, figure 2 .

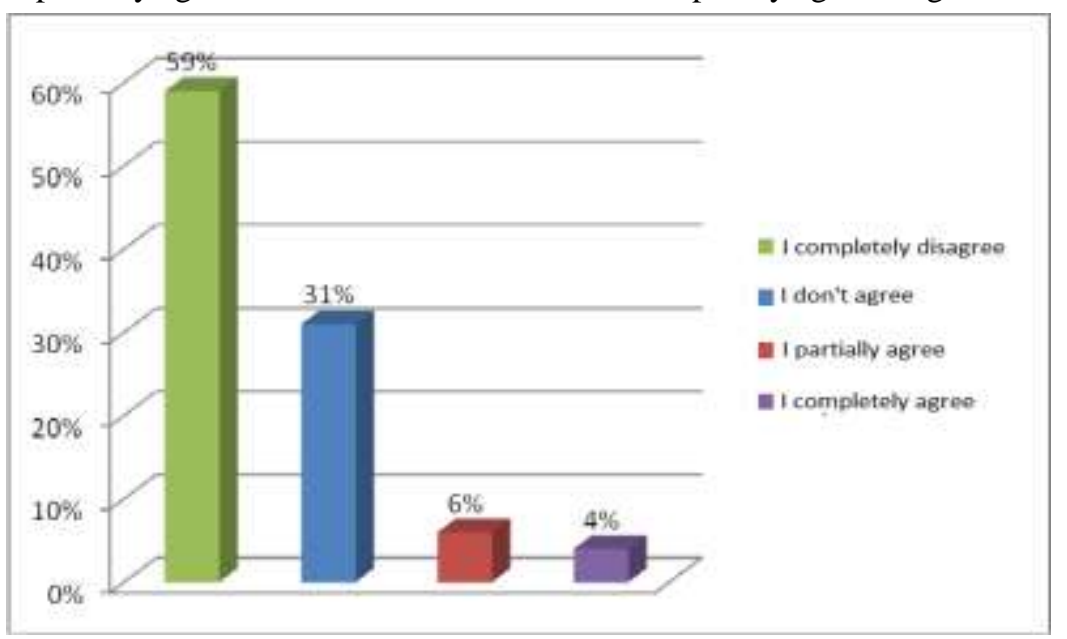

Figure 2: Satisfaction of employees with personal participation in making marketing decisions

\section{Source: Authors' research}

For the opinion: "I am at liberty to express my opinion and give suggestions concerning the improvement of company's business", we got the following answers: $54 \%$ of interviewees completely disagreed with this statement, $27 \%$ of interviewees didn't agree, $14 \%$ of interviewees partially agreed, and $5 \%$ of interviewees completely agreed, figure 3 . 


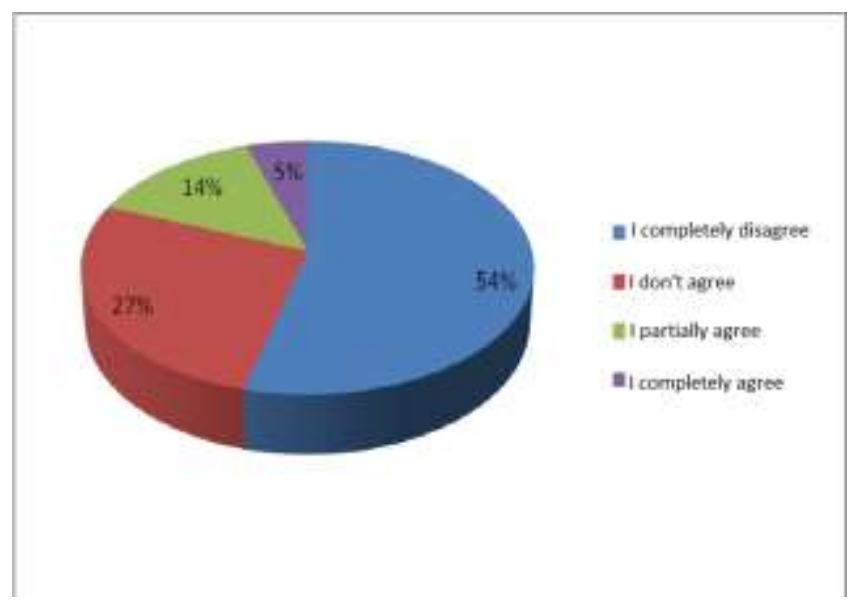

Figure 3: I am at liberty to give suggestions concerning the improvement of business

\section{Source: Authors' research}

For the opinion: "direct manager (senior manager or managing director) makes all decisions independently without consulting the employees", we got the following results: $52 \%$ of interviewees completely agreed, $27 \%$ of interviewees agreed, $15 \%$ didn't agree, while $6 \%$ completely disagreed, figure 4 .

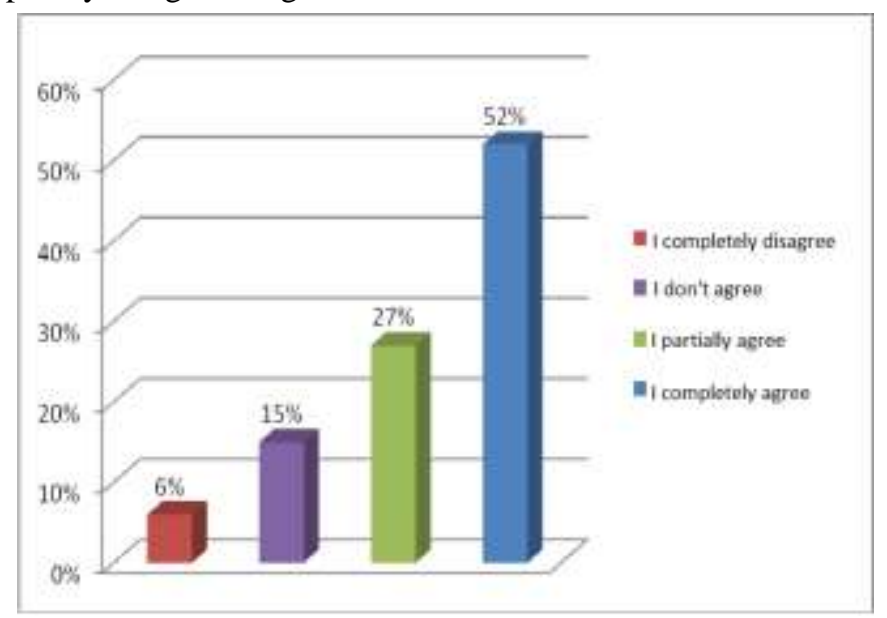

Figure 4: Marketing director makes decisions without consulting the employees

Source: Authors' research

With the opinion: "quality of marketing decisions in a company would improve if the employees would be more involved in the making of those decisions", a total of $71 \%$ completely agreed, $23 \%$ of interviewees agreed, $4 \%$ didn't agree, while $2 \%$ didn't agree at all, figure 5. It can be seen that a significant number of interviewees considered that they can make a contribution to the improvement of their company's business with their ideas in the field of marketing. 


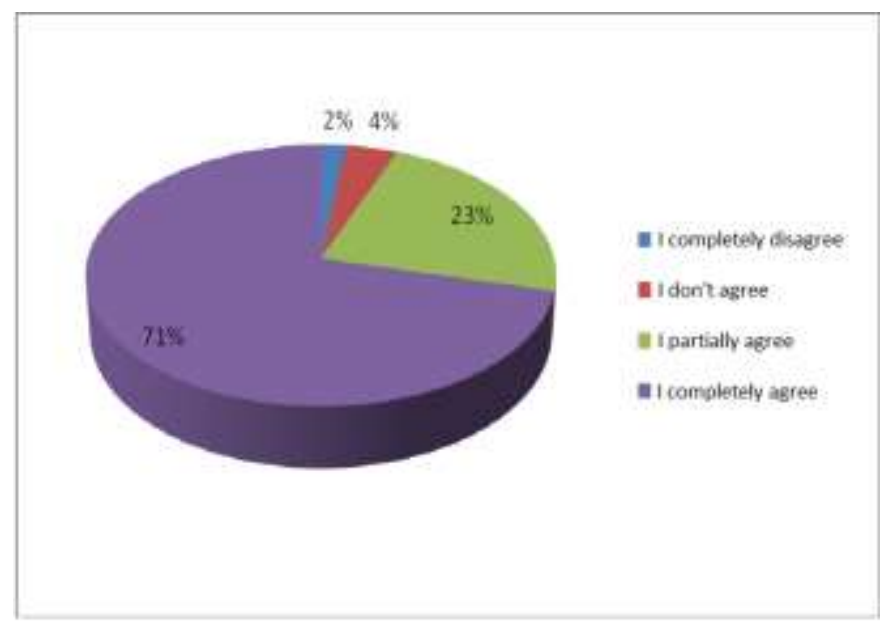

Figure 5: The quality of marketing decisions would improve if the employees would be more involved in making those decisions

Source: Authors' research

With the opinion: "I've got ideas how to improve marketing of the company I work for", $43 \%$ partially agreed, $31 \%$ of interviewees completely agreed, $15 \%$ didn't agree and $11 \%$ completely disagreed, figure 6 .

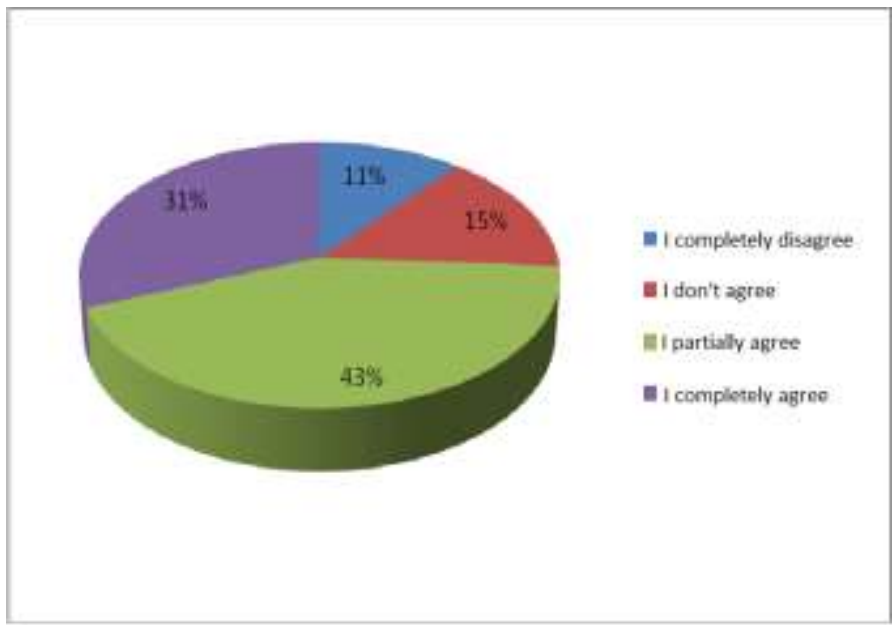

Figure 6: I've got ideas how to improve the marketing of the company I work for Source: Authors' research 


\section{CHARACTERISTICS OF EMPLOYEES AND THEIR PARTICIPATION IN MAKING DECISIONS}

In order to determine if there is a connection between personal characteristics of employees and the making of marketing decisions, we applied Pierson's correlation ${ }^{17}$, table 2 .

We can see that there is a strong positive correlation between employees' age and the liberty to express personal opinion, $\mathrm{r}=0.557$, which means that older employees are more relaxed when expressing their opinions and attitudes which can be interpreted by their greater self-confidence because they know what the business circumstances and experiences are. Older interviewees are satisfied by their involvement in making decisions (because there is a medium strong linear connection, $r=0.497$ ), and they have more ideas for improving the business, (medium string linear connection, $r=0.048$ ) and are more involved in making decisions (medium strong linear connection, $\mathrm{r}=0.396$ ). The connection between the opinion that decisions would be better with a greater participation of employees and employees' age is the opposite, which means that the younger interviewees believe that they don't participate enough in making decisions (strong correlation, $r=0.537$ ). Younger interviewees are more of the opinion that the managers are making decisions by themselves, without consulting the employees (medium strong linear connection, $r=0.368$ ).

Table 2: Correlation of employees' age and making marketing decisions

Pierson's correlation, $\mathbf{r}$

\begin{tabular}{|ll|r|}
\hline & & Age \\
\hline \multirow{3}{*}{ Involved in making decisions } & Pearson Correlation &, 396 \\
& Sig. (2-tailed) &, 000 \\
& $\mathrm{~N}$ & 100 \\
Satisfied with the involvement in & Pearson Correlation &, $497^{* *}$ \\
making decisions & Sig. (2-tailed) &, 000 \\
& $\mathrm{~N}$ & 100 \\
Free to express his/her opinion & Pearson Correlation &, $557^{* *}$ \\
& Sig. (2-tailed) &, 000 \\
Managers decide without & $\mathrm{N}$ & 100 \\
consultations & Pearson Correlation &,$- 368^{* * *}$ \\
Decisions would be better with & Sig. (2-tailed) &, 000 \\
employees' involvement & $\mathrm{N}$ & 100 \\
& Pearson Correlation &,$- 537^{* * *}$ \\
I've got ideas for improvement (2-tailed) &, 000 \\
& $\mathrm{~N}$ & 100 \\
& Pearson Correlation &, $448^{* * *}$ \\
& Sig. (2-tailed) &, 000 \\
& $\mathrm{~N}$ & 100 \\
\hline
\end{tabular}

**. Correlation is significant at the 0.01 level (2-tailed).

\section{Source: Authors' research}

In order to verify if the employees' age are significantly influencing, statistically speaking, the participation of employees in making decisions, we applied the ANOVA statistical method and the results we obtained are showed in table 3 . and figure 7.

\footnotetext{
${ }^{17}$ According to Cohen ${ }^{3}$ size of the correlation coefficient is interpreted by the strength of connection between the variables in the following way: If $r=0.1$ to 0.29 , that signifies a weak connection between the variables, if $r=0.3$ to 0.49 , it signifies a medium connection, while when $r=0.5$ to 1 it signifies a strong linear connection between two variables.
} 
Results, table 3. show that there is a statistically significant difference between employees' age and attitudes:

- I take part in the process of making marketing decisions in my company;

- I am satisfied with the level of personal participation in making marketing decisions;

- I am at liberty to express my opinion and suggestions concerning the improvement of business;

- Direct manager (senior marketing manager or managing director) makes all decisions independently without consulting the employees

- The quality of marketing decisions would improve if the employees would be more involved in the making of those decisions;

- I've got ideas concerning how a company could improve its marketing.

Table 3: ANOVA

\begin{tabular}{|c|c|c|c|c|c|c|}
\hline & & Sum of Squares & $\mathrm{df}$ & Mean Square & $\mathrm{F}$ & Sig. \\
\hline $\begin{array}{l}\text { I take part in the } \\
\text { process of making } \\
\text { decisions in my } \\
\text { company } \\
\text { I am satisfied } \\
\text { with the level of } \\
\text { involvement in } \\
\text { making decisions } \\
\text { I am at liberty to } \\
\text { express my } \\
\text { opinion and } \\
\text { suggestions } \\
\text { concerning the } \\
\text { improvement of } \\
\text { business } \\
\text { Direct manager } \\
\text { makes all } \\
\text { decisions } \\
\text { independently, } \\
\text { without } \\
\text { consulting the } \\
\text { employees } \\
\text { The quality of } \\
\text { decisions would } \\
\text { improve if the } \\
\text { employees would } \\
\text { be more involved } \\
\text { I've got an idea } \\
\text { how my company } \\
\text { could improve its } \\
\text { marketing }\end{array}$ & $\begin{array}{l}\text { Between Groups } \\
\text { Within Groups } \\
\text { Total } \\
\text { Between Groups } \\
\text { Within Groups } \\
\text { Total } \\
\text { Between Groups } \\
\text { Within Groups } \\
\text { Total } \\
\text { Between Groups } \\
\text { Within Groups } \\
\text { Total } \\
\text { Between Groups } \\
\text { Within Groups } \\
\text { Total } \\
\text { Between Groups } \\
\text { Within Groups } \\
\text { Total }\end{array}$ & $\begin{array}{r}23,501 \\
61,249 \\
84,750 \\
\\
\\
24,732 \\
18,578 \\
43,310 \\
\\
44,334 \\
62,226 \\
106,560\end{array}$ & $\begin{array}{r}4 \\
95 \\
99 \\
4 \\
95 \\
99 \\
\\
4 \\
95 \\
99\end{array}$ & $\begin{array}{r}7,077 \\
, 399 \\
\\
7,517 \\
, 323 \\
\\
11,263 \\
, 357 \\
\end{array}$ & 31,618 & ,000 \\
\hline
\end{tabular}

Source: Authors' research

Figure 7. shows how employees' age affect certain attitudes. On the $\mathrm{x}$ axis, we showed interviewees' age, and on the y axis, the level of their agreement with the opinions offered, wherein higher number denotes a higher level of agreement and vice versa.

It can be seen that employees from the 45-54 age group are of the opinion that they've got ideas which can be used to improve company's marketing, while employees over 50 and under 25 don't think so. We can presume that the youngest employees are still not 
familiar with the functioning mechanism of business and marketing while employees aged 55 and above have some other reasons. After the period in which they are highly interested and ready to give their ideas and energy with the aim to enhance company's business, there comes a period in which a massive decrease of interest occurs, which can be interpreted as a type of withdrawing and losing professional energy.

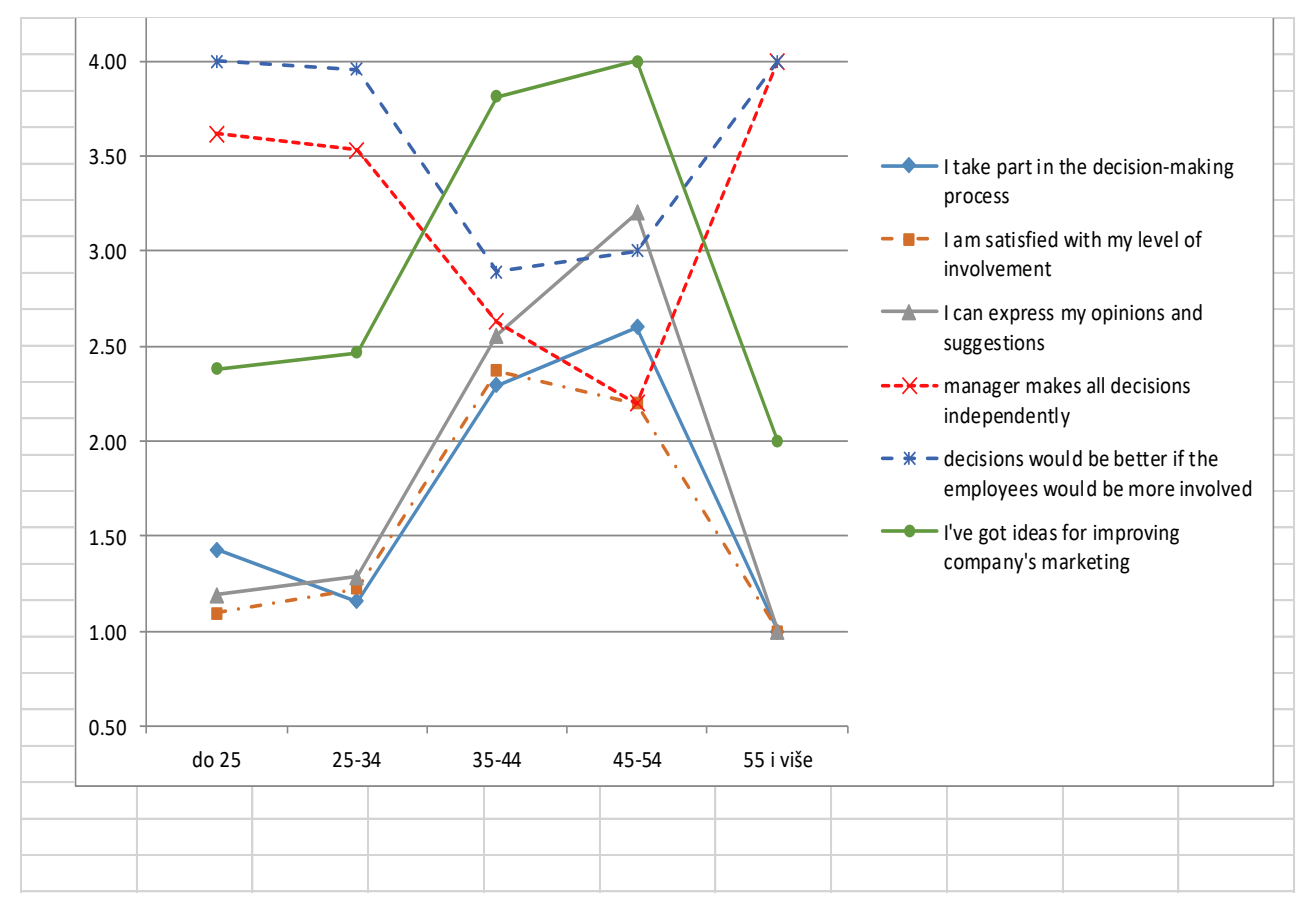

Figure 7: The influence of employees' age on making marketing decisions

\section{Source: Authors' research}

Employees aged 45-54 feel the most relaxed when it comes to expressing their opinion and participating in the decision-making process, while employees aged 55 or more as well as the younger employees cannot do that. The oldest and the youngest employees believe that the managers are making decisions independently without consulting the employees, while those with more experience and who are not in the last decade of their career don't believe so. Similar situation is when it comes to the attitude that decisions would be better when the employees would be more involved.

In order to determine the connection between the position in the organization and in advance stated attitudes about the decision-making process, we applied Pierson's correlation, table 3 . It can be seen that there is a strong positive correlation between the attitude that the employees are "at the liberty to express their opinions" and the hierarchical position in the organization, $\mathrm{r}=0.746$, which means that those at higher positions feel more relaxed when having to express themselves. Those at higher positions are also satisfied with their involvement in making decisions, $\mathrm{r}=0.662$; have more ideas for the improvement of business, $r=0.611$ and are more involved in the decision-making process, $r=0605$. Consequently, we got a strong negative correlation about the attitude that decisions would be better if the employees would be more involved, $r=.784$, because the higher the position an employee is at, the stronger the belief that decisions are made in the right way. We also got a medium strong negative correlation between the hierarchical position and the attitude 
that the manager makes decisions without previous consultations, which means that those at higher positions believe that the employees are consulted and agree less with this attitude.

Results of the obtained correlation are somewhat expected because, even though senior managers were excluded from this research, the hierarchic position in organizations affects the possibility of expressing one's opinions and by that, the involvement in the decision-making process.

Table 4: Correlation between the position and involvement in the making of decisions Pierson's correlation, $r$

\begin{tabular}{|c|c|c|}
\hline & & Position \\
\hline \multirow{3}{*}{$\begin{array}{l}\text { Involved in the decision-making } \\
\text { process }\end{array}$} & Pearson Correlation & $605^{* *}$ \\
\hline & Sig. (2-tailed) & 000 \\
\hline & $\mathrm{N}$ & 100 \\
\hline \multirow{4}{*}{$\begin{array}{l}\text { Satisfied with the participation in } \\
\text { making decisions }\end{array}$} & Pearson Correlation & $662^{* *}$ \\
\hline & Sig. (2-tailed) & 000 \\
\hline & $\mathrm{N}$ & 100 \\
\hline & Pearson Correlation & , $746^{* *}$ \\
\hline \multirow[t]{2}{*}{ Freely expresses his/her opinions } & Sig. (2-tailed) & 000 \\
\hline & $\mathrm{N}$ & 100 \\
\hline \multirow{3}{*}{$\begin{array}{l}\text { Managers make decisions without } \\
\text { consultations }\end{array}$} & Pearson Correlation &,$- 384^{* *}$ \\
\hline & Sig. (2-tailed) & 000 \\
\hline & $\mathrm{N}$ & 100 \\
\hline \multirow{4}{*}{$\begin{array}{l}\text { Decisions would be better with } \\
\text { employees' involvement }\end{array}$} & Pearson Correlation &,$- 766^{* *}$ \\
\hline & Sig. (2-tailed) & , 000 \\
\hline & $\mathrm{N}$ & 100 \\
\hline & Pearson Correlation &, $611^{* *}$ \\
\hline \multirow[t]{2}{*}{ I've got ideas for improvement } & Sig. (2-tailed) &, 000 \\
\hline & $\mathrm{N}$ & 100 \\
\hline
\end{tabular}

**. Correlation is significant at the 0.01 level (2-tailed).

Source: Authors' research

\section{DISCUSSION AND CONCLUSION}

Research presented in this paper pointed out to the fact that there was a problem concerning the participation of employees in the process of making marketing decisions in enterprises in the Republic of Serbia, because a great number of employees are not involved and have no possibility of making a contribution to this process. Consequently, we can come to a conclusion that the basic hypothesis of this research was confirmed, i.e. by increasing the level of employees' participation in the process of making marketing decisions in enterprises in the Republic of Serbia, their business could be improved. A special research hypothesis which says that personal characteristics of employees influence their involvement in the decision-making process was also confirmed because we got significant differences depending on the age of interviewees and hierarchical position in the organization, even though senior managers were excluded from this research. That points out to a strict hierarchical constellation in organizations which can present an obstacle for creativity, especially in the sphere of marketing. 


\section{REFERENCES}

[1] Barković, D. (2009). Menadžersko odlučivanje, Osijek, Ekonomski fakultet.

[2] Kirin, S. (2006). Prilog razvoju modela donošenja odluka u organizaciji, Magistarski rad, Fakultet tehničkih nauka u Novom Sadu.

[3] Kirin, S., Grubić-Nešić, L. (2008). Istraživanje procesa donošenja odluka u realnim uslovima, 35 Simpozijum o operacionim istraživanjima, SYMOPIS 2008.

[4] Kirin, S., Grubić-Nešić, L. Cosic, I. (2010). Increasing a large petrochemical company efficiency by improvement of decision making process', Chemical Industry 64(5), 465472.

[5] Milošević, D. Strategija rasta i razvoja preduzeća. Visoka škola za poslovnu ekonomiju i preduzetništvo, Beograd. 2012.

[6] Mucunska-Palevska, V., Badarovski, T. (2013). The role of talent management in the development of the marketing team. International Review (No.3-4), str. 97-111. Beograd, visoka škola za poslovnu ekonomiju i preduzetništvo.

[7] Ravić, N., Milošević, D., Minkov, Đ. (2013). Globalne Internet marketing strategije i njihove implikacije na mala i srednja preduzeća. Druga međunarodna naučna konferencija pod nazivom: Zapošljavanje, obrazovanje i preduzetništvo. Knjiga: Polna, IT i marketing pitanja u preduzetništvu, str. 246-262. Beograd, Visoka škola za poslovnu ekonomiju i preduzetništvo.

[8] Ravić, N., Minkov, Đ. (2014). Konkurentske marketing strategije. Treća međunarodna naučna konferencija pod nazivom: Zapošljavanje, obrazovanje i preduzetništvo. Knjiga: Menadžment, marketing i komunikacija: tekući i budući trendovi, str. 186-212. Beograd, Visoka škola za poslovnu ekonomiju i preduzetništvo.

[9] Turban, E., McLean, E., Wetherbe, J. (2003). Informaciona tehnologija za menadžment. Zavod za udžbenike i nastavna sredstva, Beograd

\section{Article history:}

- $\quad$ Received 31 August 2016

- Accepted 10 October 2016 